\title{
EFEKTIFITAS GAYA KEPEMIMPINAN DALAM MEMANAJEMEN RODA PEMERINTAHAN MASYARAKAT DESA TORJUNAN KABUPATEN SAMPANG
}

\author{
Arnanda Ajisaputra \\ Sekolah Tinggi Ilmu Ekonomi Indosakti Malang \\ E-mail: paranggaruda@gmail.com
}

\begin{abstract}
The research objective was to clarify the effectiveness of leadership style of Torjunan headman in terms of bureaucratic leadership that leads to its function as part of the Indonesian government institutions at the village level, and in terms of Situational Leadership leading to its function as the leader and protector of society. The instruments used in data collection were interviews, observation, and documentation; which further examined using three methods of data analysis namely; Miles analysis, which covered: data collection, data reduction, data presentation, and conclusion; Reddin analysis consisting of synchronization, data input, as well as the calculation of the average; and Hersey and Blanchard analysis comprising: synchronization, data input and drawing conclusions based on the accumulative column. The results showed: 1) Torjunan headman was seem less flexible in terms of managing the issues related to government affairs, especially regarding the bureaucratization of Robatal sub-district; 2) based on Blanchard Situational Leadership II model, Torjunan headman style were classified into G4 category, which means that Torjunan headman would be able to work more effective if he delegated the decision-making, as well execution, to society.
\end{abstract}

Keywords: Effectiveness of Leadership Styles, Situational, Bureaucratic, Torjunan headman (klebun)

\begin{abstract}
Abstrak
Tujuan penelitian untuk mengetahui efektifitas Gaya Kepemimpinan Klebun Torjunan dilihat dari segi Kepemimpinan Birokratis yang mengarah pada fungsi Klebun sebagai bagian dari lembaga pemerintahan Indonesia di tingkat desa, maupun dari segi Kepemimpinan Situasional yang mengarah pada fungsi Klebun sebagai pemimpin dan pengayom masyarakat. Teknik pengumpulan data dilakukan dengan wawancara, observasi dan dokumentasi dan analisis data menggunakan analisis Miles Huberman yang terdiri dari: pengumpulan data, reduksi data, penyajian data, dan penarikan kesimpulan; analisis Reddin yang terdiri atas sinkronisasi, input data serta penghitungan rata-rata; serta analisis Hersey \& Blanchard yang terdiri atas: sinkronisasi, input data serta penarikan simpulan berdasarkan kolom akumulatif. Hasil penelitian menunjukkan: 1) Klebun Torjunan kurang luwes dalam memanajemen laju roda pemerintahan khususnya menyangkut birokratisasi dengan pemerintah Kecamatan Robatal; 2) Efektifitas Gaya Kepemimpinan Situasional Klebun Torjunan berada pada klasifikasi $G_{4}$, yang menggambarkan Klebun Torjunan lebih efektif melakukan tindakan dengan cara melimpahkan pembuatan keputusan dan pelaksanaan kepada masyarakat.
\end{abstract}

Kata kunci: Efektifitas Gaya Kepemimpinan, Situasional, Birokratis, Klebun Desa Torjunan 
Ekonomika-Bisnis Vol. 5 No.1 Bulan Januari Tahun 2014. Hal 23-44

Hai orang-orang yang beriman, taatilah Allah dan taatilah Rasul-Nya, dan ulil amri di antara kamu. Kemudian jika kamu berlainan pendapat tentang sesuatu, maka kembalikanlah ia kepada Allah dan Rasul, jika kamu benar-benar beriman kepada Allah dan hari kemudian. Yang demikian itu lebih utama (bagimu) dan lebih baik akibatnya (Al-Qur'an, 4:59). Dalam ayat ini Tuhan Semesta Alam memerintahkan kepada para hamba-hambaNya untuk taat kepada para pemimpinnya, sebab manusia merupakan makhluk sosial yang hidup secara berkelompok dan bermasayarakat. Kehidupan tersebut menimbulkan suatu interaksi sosial antara individu yang satu dengan yang lainnya sehingga timbul aktivitas sosial yang kompleks (Soekanto, 2005: 61). Aktivitas sosial yang kompleks tersebut akan berjalan dengan teratur bila ada seorang pemimpin yang mampu untuk melakukan pendekatan kepada masyarakat serta memahami budaya, ciri khas, dan sifat-sifat masyarakatnya.

Bila seorang pemimpin tidak bisa memahami masyarakatnyakhususnya dalam segi sosial dan budaya, maka permasalahan demi permasalahan akan timbul di tengah-tengah masyarakat. Sebagaimana hal ini disampaikan oleh Rasulullah, "Apabila amanat telah disia-siakan, maka tunggulah kedatangan hari kiamat." Abu Hurairah bertanya, "Bagaimana menyia-nyiakannya itu, wahai Rasulullah?'. Beliau menjawab, "Apabila suatu urusan diserahkan kepada yang bukan ahlinya, maka tunggulah datangnya harikiamat". (Shahih Bukhari, kitab Ar-Riqaq, Bab Raf' il Amanah 11: 333). Oleh sebab itu pemimpin harus ahli dalam memimpin serta mengetahui bagaimana cara memimpin yang tepat agar terwujud tatanan masyarakat yang sejahtera sesuai dengan harapan Bangsa Indonesia yang tercantum dalam preambule UUD 1945.
Negara Indonesia yang merupakan negara majemuk, memilikiberagam suku bangsa, budaya, dan bahasa, merupakan tantangan tersendiri bagi seorang pemimpin untuk mengatur masyarakatnya. Interaksi sosial yang majemuk memunculkan norma-norma sosial yang berperan untuk mengatur pergaulan hidup dengan tujuan untuk mencapai suatu tata tertib (Soekanto, 2005: 198). Agar normanorma yang mewujudkan tata tertib tetap bertahan, maka ada suatu kekuatan (power) dalam masyarakat yang berfungsi untuk menjaga stabilitasnya. Tentunya kekuatan tersebut tidak hanya dilakukan oleh seorang individu saja, namun sekumpulan dari individu yang membentuk suatu lembaga. Pernyataan ini sesuai dengan apa yang diungkapkan oleh Soekanto (2005: 198), 'Untuk memberikan suatu batasan, dapatlah dikatakan bahwa lembaga kemasyarakatan merupakan himpunan norma-norma segala tingkatan yang berkisar pada suatu kebutuhan pokok di dalam kehidupan masyarakat".

Lembaga kemasyarakatan bila diwujudkan dalam ruang lingkup suatu negara disebut sebagai pemerintah. Menurut Haricahyono (1986: 63) yang dimaksud pemerintah adalah mesin yang dipakai untuk mengatur rakyat atau penduduk yang tinggal dalam suatu wilayah negara. Pemerintah Indonesia saat ini telah mengakui otoritas pemerintah daerah sehingga dibentuklah sistem pemerintahan otonomi daerah, sehingga masing-masing daerah memiliki hak dan wewenang untuk mengatur wilayahnya sesuai dengan kondisi lingkungan serta sosial kemasyarakatannya tanpa melenceng dari program utama yang dirancang oleh pemerintah pusat. Maka pemimpin suatu wilayah benar-benar harus memahami wilayahnya dan masyarakatnya secara menyeluruh agar roda pemerintahan berjalan dengan baik. Apabila sistem otonomi da- 
erah diwujudkan pada ruang lingkup masyarakat desa, maka kepala desa harus memahami betul kondisi wilayahnya yang meliputi potensi alam terlebih lagi potensi Sumber Daya Manusia (SDM) yang merupakan unsur utama suatu daerah di negara Indonesia.

Untuk mencetak pemimpin yang ahli dalam memerintah dan mengatur masyarakat, maka diperlukan gaya kepemimpinan yang efektif untuk mewujudkan masyarakat yang madani, patuh terhadap aturan-aturan yang berlaku serta bersemangat dalammembangun wilayahnya sehingga terwujud kesejahteraan di wilayah Negara Kesatuan Republik Indonesia (NKRI). Thoha (1983:51) menyatakan bahwa pada saat seseorang berusaha mempengaruhi orang lain, maka ia terlibat dalam aktivitas kepemimpinan. Jika kepemimpinan tersebut terjadi dalam suatu organisasi tertentu dan perlu mengembangkan staf serta membangun iklimmotivasi yang membangun tingkat produktivitas tinggi, maka orang tersebut lantas perlu memikirkan gaya kepemimpinannya. Dalam pemerintahan desa gaya kepemimpinan tentunyaharus disesuaikan dengan pola sosial masyarakat setempat, sehingga dalam proses kepemimpinan konflik sosial dapat diminimalisir agar program kerja pemerintah dapat berjalan dengan lancar.

Madura merupakan sebuah pulau di sebelah Timur Laut Pulau Jawa yang memiliki karakteristik masyarakat yang unik, terkenal akan semangat dan kerja keras, serta dikenal dengan sifat dan wataknya yang keras. Masyarakat di pedesaan pada umumnya bersifat sederhana dalam pemikirannya maupun tindakannya. Biasanya mereka bersifat tertutup dan enggan untuk berhubungan dengan orang lain, sulit diharapkan untuk berinisiatif sendiri baik secara individu maupun kelompok (Sepoetro, 1980: 191). Kondisi yang demikian dapat menghambat program-pro- gram yang telah dibentuk oleh pemerintah, baik pemerintah pusat maupun pemerintah daerah Republik Indonesia.

Di Madura pemimpin yang diakui adalah pemimpin yang mempunyai pengaruh tinggi terhadap masyarakat. Ia dinilai oleh masyarakat sebagai orang yang berwibawa dan mempunyai nilai kehormatan yang tinggi di dalam nasabnya. Ketika otonomi daerah diterapkan di Indonesia, pemimpin daerah dipilih langsung oleh masyarakat sehingga peran dan tanggung jawabnya menjadilebih besar, sebab masyarakat telah memberikan kepercayaan penuh kepadanya untuk mengayomi mereka sehingga terwujud kehidupan masyarakat yang sejahtera.

Sampang merupakan salah satu kabupaten di Pulau Madura yang terkenal dengan kultur masyarakat yang keras. Pengetahuan mereka di bidang pemerintahan telah berkembang dan menuai sikap kritis pada masyarakatnya. Ketidaksesuaian sikap pemimpin terhadap masyarakat merupakan suatu permasalahan tersendiri yang menuai konflik besar. Konflik besar yang pertama kali muncul di Indonesia terjadi di Kabupaten Sampang pada tanggal 29Mei 1997. Genap satu tahun sebelum Jakarta dipenuhi demonstrasi mahasiswa, Kabupaten Sampang dipenuhi dengan aksi anarkis oleh masyarakat. Pembunuhan dan perusakan fasilitas umum terjadi hampir di seluruh kawasan wilayah Kabupaten Sampang karena tidak puas dengan sistem kepemimpinan pada saat itu (Rubrik Peristiwa, 28 Juni 1997). Pada era reformasi di mana otonomi daerah telah diberlakukan, pengetahuan masyarakat tentang politik dan pemerintahan menjadi lebih berkembang sehingga membutuhkanperan pemimpin yang handal dalammemerintah wilayah Madura pada umumnya dan Kabupaten Sampang pada khususnya. 
Pengetahuan masyarakat tentang pemerintahan juga telahberkembang pesat didaerah pedesaan. Seperti yang terjadi di Desa Torjunan Kecamatan Robatal yang terletak seki$\operatorname{tar} 24 \mathrm{Km}$ arah utara dari Pendopo Kabupaten Sampang. Keadaan wilayahnya yang gersang dan sulitnya mendapatkan sumber air bersih menjadi salah satu penyebab kerasnya kultur masyarakat setempat.

Desa Torjunan dipimpin oleh seorang kepala desa, masyarakat Madura menyebutnya denganistilah Klebun. Setelahotonomi daerah diterapkan, masyarakat desa setempat mulai merasakan kebebasan berpolitik. Kultur masyarakat yang keras dan terbuka menambah keberanian mendatangi Klebun untuk meminta kejelasan tentang suatu permasalahan yang terjadi di tengah-tengah masyarakat. Penjelasan yang disampaikan Klebun kepada masyarakat tidak sekedar penjelasan yang tepat dan akurat, tetapi memerlukan gaya kepemimpinan tersendiri yang cocok untuk dapat mempengaruhi masyarakat sehingga masyarakat tidak anarkis bertindak beringas dan brutal, melainkan masyarakat mau menerima penjelasan dan mau menuruti perintah Klebun.

Berdasarkan studipendahuluan yang dilakukan pada saat melaksanakan KKN diketahui bahwa, masyarakat Desa Torjunan yang terkenal keras, terbuka dan pemberani, ternyata mau berpartisipasi aktif di bawah kepemimpinan Klebun untuk secara bersama-sama mewujudkan kesejahteraan masyarakat. Keberhasilan kepemimpinan Klebun dalammempengaruhimasyarakat initidak semudah membalikkan tangan, karena di satu sisi dihadapkan pada sistem birokratis yang telah diatur oleh Undang-Undang Negara Kesatuan Republik Indonesia, di sisi lain Klebun yang berperan sebagai pamong masyarakat dihadapkan pada situasional untuk pemenuhan kebu- tuhan praktis yang bertentangan dengan sistem kepemimpinan birokratis.

Salah satu studikasus menunjukkan bahwa masyarakat desa Torjunan sangat memerlukan pemenuhan kebutuhan air bersih. Pemenuhan kebutuhan ini harus segera dipenuhi dan tidak memerlukan penanganan secara birokratis melalui jalur hirarkhis yang begitu panjang. Apabila hal ini tidak segera dipenuhi dapat sebagai penyebabkerawanan sosial yang berdampak kompleks. Sebagai mediator antara pemenuhan kebutuhan situasional masyarakat Desa Torjunan dengan secara birokratis melalui jalur hirarkhis Pemerintah Kecamatan Robatal diperlukan gaya kepemimpinan yang efektif pada Klebun Torjunan. Ada dua jenis gaya kepemimpinan Klebun yang ditengarai efektif dalam mengatasi permasalahan yang terjadi di desa Torjunan. Dua jenis gaya kepemimpinan itu adalah Gaya Kepemimpinan Situasional dan Gaya Kepemimpinan Birokratis. Gaya Kepemimpinan Situasional berperan penting dalam mewujudkan komunikasi dan interaksi antara Klebun Torjunan dengan Masyarakat Desa Torjunan dan Gaya Kepemimpinan Birokratis berperan penting dalam mewujudkan komunikasi dan interaksi antara Klebun Torjunan dengan Kecamatan Robatal.

Gaya Kepemimpinan Situasional dan Gaya Kepemimpinan Birokratis akan efektif diterapkan dalam menjalankan roda pemerintahan apabiladidukung dengan penerapan yang tepat di lapangan. Oleh karena itu peneliti tertarik untuk menggambarkan seberapa besar efektifitas gaya kepemimpinan Klebun Torjunan baik dilihat dari Gaya KepemimpinanBirokratis maupun Gaya Kepemimpinan Situasional. 
Efektifitas Gaya Kepemimpinan dalam Memanajemen.... (Arnanda Ajisaputra)

\section{Metode Penelitian}

Dengan mengacu kepada tujuan yang ingin dicapai dalampenelitian ini yaitu mendeskripsikan gaya kepemimpinan Klebun Torjunan Kabupaten Sampang, serta mengidentifikasi serta menganalisis efektifitas gaya kepemimpinan yang tepat untuk diterapkan dari kedua gaya kepemimpinan yaitu birokratis dan situasional, maka penelitian ini dapat digolongkan ke dalam penelitian deskriptif kualitatif.

Lokasi penelitian merupakan tempat di mana riset penelitian akan dilakukan. Lokasi penelitian yang akan diambil oleh peneliti adalahDesa Torjunan, Kecamatan Robatal, Kabupaten Sampang Madura. Tepatnyaadalah sekitar $24 \mathrm{Km}$ sebelah Utara Kota Sampang.

Agar penelitian dapat fokus pada suatu permasalahan sehingga menghasilkan deskripsi yang lebih obyektif, maka penelitimemberikan batasan sebagai berikut: Obyek Penelitian: Peneliti membatasi obyek penelitian pada Klebun/Kepala Desa Torjunan Kabupaten Sampang, aparat pemerintah Kecamatan Robatal Kabupaten Sampang, serta masyarakat Desa Torjunan Kabupaten Sampang.

Terdapat 3 (tiga) pendekatan dalampenelitian sosial kualitatif yang menyangkut pendekatan Fenomenologi, Interaksi Simbolik, dan Etnometodologi(Hendarso, 2006: 166).

Berdasarkan pernyataan di atas, maka peneliti menggunakan metode survey dan studikasus sebagailangkah untukmelakukan pendekatan secara menyeluruh terhadap obyek penelitian.

Sedangkan pendekatan teori yang dipakai adalah Pendekatan Teori Reddin dan Teori Hersey\&Blanchard. Pendekatan Teori Reddin digunakan untuk menganalisa dan mendeskripsikan Gaya Kepemimpinan Birokratsi Klebun Torjunan. Mengingat Klebun/Kepala Desa adalah seseorang pemim- pin yang memegang tanggung jawab tertentu sebagai pemimpin dan memiliki sejumlah peraturan-peraturan yang harus dilaksanakan dan terkait dengan sistem administrasi pemerintahan. Peranan Pendekatan Teori Reddin adalah menganalisa dan menggambarkan bagaimana efektifitas Gaya Kepemimpinan Birokratis Klebun Torjunan melalui sudut pandang perangkat pemerintahan di atasnya (camat) dan melalui sudut pandang masyarakat desa setempat dalam kaitannya dengan penerapan administrasi pemerintahan daerah setempat.

Pendekatan Teori Hersey\&Blanchard digunakan untuk menganalisa dan mendeskripsikan Gaya Kepemimpinan Situasional Klebun Torjunan. Mengingat Klebun Torjunan merupakan seorang pamong bagi masyarakat Desa Torjunan yang bertanggungjawab atas kesejahteraan serta keamanan masyarakat Desa Torjunan. Peranan Pendekatan Teori Hersey\&Blanchard sebagai alat analisis untuk menganalisa dan menggambarkan jenis Gaya Situasional yang dipakai Klebun Torjunan beserta efektifitasnya terhadap masyarakat Desa Torjunan dalam kaitannya dengan fungsi Klebun/Kepala Desa sebagai pamong/pengayom masyarakat.

Mengingat jumlah obyek data yang sangat banyak dan terdiri atas berbagai lapisan masyarakat serta fungsi obyek data yang vital untuk mendapatkan sumber data primer agar hasil penelitian dapat obyektif, maka peneliti menggunakan teknik Quota Sampling yang akan dijelaskan pada paragraf berikutnyauntuk menentukansample obyek yang akan diteliti.

Dalampenelitian ini, peneliti akan menggunakan Non Probability Sampling dengan menggunakan sistem Quota Sampling. Non Probability Sampling digolongkan sebagainon random sampling, sebab tidak memperhitung- 
kan variasi antara setiap unit sampling dan kemungkinan kekeliruan sampel. Jumlah populasi sering tidak diketahui dengan pasti, sehingga pengambilan jumlah atau ukuran sampel hanya dilakukan dengan perkiraan atau estimasi telah mencukupi untuk mewakili populasi (Nawawi, 2005: 156).

Penelitimelakukan analisis data dengan menggunakan model interaktif dan pendekatan teori. Model interaktif terdiri atas tiga komponen analisis yaitu, reduksi data, sajian data, dan penarikan kesimpulan (Milles dan Huberman dalam Sujadi, 2005: 60). Selanjutnya ketiga komponen ini dipadukan secara sistematis untuk menambah keakuratan analisa. Perpaduan ketiga komponen dalam model analisa data interaktif ini dapat digambarkan dalam bagan seperti berikut:

Pendekatan teori yang digunakan adalah Grand Theory of Hersey and Blanchard dan Grand Theory of Reddin (Teori Pokok dari Hersey dan Blanchard serta Teori Pokok dari Reddin).

Teori Hersey dan Blanchard merupakan teori yang dipakai dalammenganalisa Efektifitas Gaya Kepemimpinan Situasional yang diterapkan oleh Klebun Torjunan dalam kepemimpinannya sekaligus klasifikasi gaya yang tepat untuk diterapkan sesuai dengan kondisi dan situasi saat peneliti berada di lapangan. Pendekatan ini didasarkan atas pernyataan Hersey dan Blanchard yang dituangkan dalam model gaya kepemimpinan situasional yang telah dimodifikasi oleh para ilmuwan setelahnya sebagai alatukur. Untuk dapat mengukur efektifitas dan klasifikasi gaya yang tepat yaitu dengan cara mengklasifikasikanfield note ke dalam tabel yang telah disiapkan. Kemudian setelah selesaimaka hasil klasifikasi dicocokkan ke dalam model teoriyang ada. Model dan alat ukur penelitian akan peneliti cantumkan dalam Bab Lampiran.
Sedangkan pendekatan Teori Reddin digunakan untuk mengukur efektifitas Gaya Kepemimpinan Birokratis Klebun/Kepala Desa Torjunan. Pendekatan ini didasarkan atas pernyataan Reddinmenyangkut Gaya Kepemimpinannya. Untuk mengetahui efektifitas Gaya Kepemimpinan Birokratis Klebun/Kepala Desa Torjunan, peneliti akan memasukkan informasi yang didapatkan dari data-data primer ke dalam Grand Theory Model of Reddin. Darimodelteori utama tersebut, efektifitas Gaya Kepemimpinan Birokratis Klebun Torjunan dapat diidentifikasi. Model dan alat ukur penelitian akan peneliti cantumkan dalam Bab Lampiran.

\section{Hasil Penelitian dan Pembahasan}

Karena studi kasus penelitian ini membahas mengenai Efektifitas Gaya Kepemimpinan Birokratis Klebun Torjunan, maka obyek yang diteliti adalah pegawai Kecamatan Robatal yang sering berinteraksi dengan Klebun Torjunan dalampertemuan formal maupun informal. Mereka adalah Camat Robatal dan para Kepala Bagian yang membawahiCamat. Informasi yang mereka sampaikan telah mendeskripsikan secara detail Gaya Kepemimpinan Birokratis Klebun Torjunan melalui fenomena atau kejadian-kejadian yang dikemukakan. Selain itu informasitersebut dapat dijadikan sebagai bahan untuk menentukan gambaran Efektifitas Gaya Kepemimpinan Birokratis secara tertimbang yang diukur dengan metode pengukuran Reddin.

Bila digambarkan secara fenomenal, terdapat situasi, kondisi, maupun kejadian di lapangan yang cukup unik dan menarik untuk menggambarkan Gaya Kepemimpinan Birokratis Klebun Torjunan, mengingat budaya Madura khususnya Desa Torjunan jarang dibahas dalam suatu penelitian oleh para peneliti. 
Adapun gambaran tersebut meliputi: Masalah AdministrasiPernikahan (Pembuatan Surat Nikah), masyarakat Madura, termasuk juga masyarakat Desa Torjunan masih banyak ditemuiperkawinan dibawah umur yang ditentukan oleh Undang-Undang Perkawinan Republik Indonesia, di mana dalamUndang-Undang tersebut dinyatakan bahwa usia minimal menikah bagilaki-laki adalah 21 Tahun dan wanita adalah 18 Tahun. Namun demikian, dikarenakan pendidikanmasyarakat yang rendah ditunjang dengan norma agama dan budaya yang kental Undang-Undang Perkawinan Republik Indonesia kurang begitu dipedulikan. Pada akhirnya banyak dari mereka yang tidak memiliki buku catatan pernikahan di KUA.

Permasalahan demi permasalahan terus berkembang seiring dengan kebutuhan mereka, khususnya bagi pendidikan anak-anak mereka di mana administrasi pendidikan telah disyaratkan dengan ketat. Kejelasan akta kelahiran termasuk salah satu syarat yang harus dipenuhi, sehingga bagi mereka yang tidak memiliki surat nikah, akta kelahiran anak mereka tidak bisa diterbitkan. Hal ini memicu permasalahan lebih jauh yang menjadi beban seorang Klebun sebagai pengayom masyarakat untuk segera mengambil jalan keluar bagi permasalahan masyarakatnya khususnya masalah pernikahan.

Permasalahan yang tampak dari kebiasaan mereka untuk menikah di bawah umur menurut Undang-Undang Pernikahan adalah masyarakat yang tidak memiliki surat nikah, sehingga ketika mereka mempunyai anak akan sulit untuk medapatkan akta kelahiran anakanak mereka. Hal ini akan menyulitkan pula dalam masalah pendidikan anak mereka, sebab pendidikan untuk saat ini mensyaratkan memiliki akta kelahiran sebagai syarat utama. Akhirnya banyak di antara mereka yang ti- dak bersekolah, atau minimal tamatan $\mathrm{Se}$ kolah Dasar yang dikelola secara tidak formal oleh beberapa organisasi kemasyarakatan.

Seandainya mereka berniat mengurus surat nikah di masa tuanya atau ketika mereka telah memiliki anak hal itu bisa dilakukan, namun memerlukan persyaratan yang rumit dengan biaya yang mahal serta proses administrasi yang tidak mudah. Mereka diharuskan membayar biaya administrasi sebesar satu juta rupiah dan wajib mengikuti sidang agama di KUAdengan menghadirkan saksi-saksi.

Selain itu permasalahan berkembang terus dan menjadi permasalahan yang melekat di saat anak-anak mereka telah memiliki kebutuhan untuk mengurus administrasisipil yang lain seperti KTP, akta jual-belitanah, serta warisan. Hal ini sering terjadi dan memunculkan permasalahan pelik karena anak-anak mereka tidak tahu berapa usianya. Akhirnya dalam penerapan di lapangan, anak-anak mereka pun menyatakan umurnya dengan perkiraan dan karangan semata.

Dua sisiyang harus dipertimbangkan oleh Klebun Torjunan adalah bagaimana Beliau dapat melayani masyarakatnya untuk mempermudah administrasi mereka khususnya pernikahan mereka bagi yang akan menikah. Di sisi lain secara hukum dan Undang-Undang Pernikahan, Klebun tidak bisa lepas dari ketentuan yang berlaku. Inilah pentingnya peran Gaya Kepemimpinan Birokratis harus betul-betul diterapkan secara efektif agar masyarakat terpenuhi kepuasannya dan di sisi lain tidak menyalahi aturan yang berlaku.

Gaya Kepemimpinan Birokratis inimerupakan gaya kepemimpinan yang berfungsi untuk memediasi antara masyarakat dengan pemerintahyang lebihtinggiwewenangnya. Sehingga Klebun dalam menerapkan Gaya Kepemimpinan Birokratis adalah bagaimana 
Ekonomika-Bisnis Vol. 5 No.1 Bulan Januari Tahun 2014. Hal 23-44

beliau dapat memahamkan perilaku masyarakat yang berkaitan dengan birokratis ataupun administrasi kepada aturan-aturan yang berlaku sehingga tidak terjadi penyimpangan-penyimpangan dan masalah-masalah administrasi yang menyulitkan masyarakat. Atau bila perilaku tersebut telah diklaim masyarakat secara mayoritas sebagai adat maupun aturan agama, maka peran Klebun adalah bagaimana beliau dapat meyakinkan pihak pemerintah bahwa itu adalah adat yang dipegang teguh oleh masyarakat sehingga pemerintah dapat memberikan kebijakan lain yang meringankan masyarakat.

Bila sistem birokratis seperti contoh di atas yaitu masalah pernikahan diterapkan secara kaku, yaitu berjalan sesuai dengan Undang-Undang Pernikahan yang berlaku tanpa melihat bagaimana situasi kondisi, budaya dan kebiasaan di suatu daerah khususnya diMadura maka akan menimbulkan permasalahan yang lebih besar mulai dari ketidakpuasan masyarakat hingga kerusuhan masal, bahkan carok pun bisa terjadi sewaktu-waktu. Selain itu khususnya di Madura termasuk di Desa Torjunan, karakteristik masyarakatnya yang keras harus menjadi pertimbangan tersendiri bagi aparat pemerintahan desa.

Koordinasi dan Administrasi, Klebun Torjunan pada khususnya juga harus menerapkan kemudahan-kemudahan dalam sistemadministrasi termasuk juga pembuatan surat nikah ataupun akta kelahiran. Pemerintah Kecamatan Robatal dan Kabupaten Sampang pun telah memakluminya, karena selain kondisi masyarakatnya yang memiliki tempramen keras dengan pendidikan yang rendah juga ditunjang sistem koordinasi Klebun terhadap para pejabat di atasnya (Camat dan Bupati) dalam melaporkan kesiapan masyarakatnya untuk menerima sistem administrasi yang berlaku umum di Negara Kesatuan Republik Indonesia.
Dengan adanya fleksibilitas terhadap sistemadministrasi di wilayah Desa Torjunan pada khususnya, maka desa ini termasuk desa yang paling aman di wilayah Kecamatan Robatal khususnya dari informasi tentang meletusnya konflik hingga menimbulkan carok, walaupun benih-benih permusuhan masih tetap ada. Kondisi demikian tidak dialami oleh desa yang lainnya, konflik masyarakat yang menyangkut tentang permasalahan dalam pemerintahan seringkali menimbulkan situasi genting yang berujung pada tawuran massal hingga carok, walaupun untuk saat inimasalah carok jauh berkurang di wilayah Madura pada umumnya.

Gaya Kepemimpinan Birokratis yang ditinjau dari segi hubungan Klebun dengan pihak kecamatan, merupakan suatu sarana untuk menggambarkan bagaimana situasi dan kondisi masyarakat khususnya di Desa Torjunan.

Berdasarkan hasil wawancara yang dipaparkan pada subbab4.3 menunjukkan bahwahubungan antara Klebun dengan pihak kecamatan cukup baik, namun kurang memiliki fungsi dan peranan yang signifikan. Berdasarkan kesimpulan hasil wawancara diperoleh suatu gambaran bahwa pihak pemerintah Kecamatan Robatal hanya berperan sebagai mediasi dan kontrol terhadap desadesa di seluruh Kecamatan Robatal termasuk Desa Torjunan. Sehingga bila terjadi masalah dalam proses pembangunan, maka Klebun lebih sering menangani kasusnya dengan masyarakat secara langsung daripada harus berkoordinasi dengan Camat atau meminta pendapat pihak kecamatan. Seandainya memang perlu dilakukan hubungan dengan pihak kecamatan itu hanya sebatas sistem administrasi fungsional. Pada aplikasinya Klebun lebih memilih koordinasi intensif dengan Bupati daripada dengan Camat. Kondisi demikian salah satunya disebabkan karena Ke- 
camatan Robatal tidakmemiliki anggaran dana sama sekali untuk pembangunan desadesa di seluruh Kecamatan Robatal termasuk Desa Torjunan. Di sisi lain pihak Kecamatan Robatal tetapmemilikitanggung jawabmerekam aktivitas sosial kemasyarakatan dan pembangunan desa-desanya. Maka para Klebun termasuk Klebun Torjunan lebih memilih koordinasi dan konsultasi dengan Bupati Sampang daripada dengan Camat Robatal, namun secara tanggung jawab fungsional Klebun tetap memberitahukan pihak kecamatan tentang kondisi desanya.

Selain itu pihak Kecamatan Robatal tidak memiliki aparat keamanan khusus yang memadai. Di satu sisi kondisi keamanan dan sosial masyarakat di seluruh desa Kecamatan Robatal termasuk Desa Torjunan sangat labil, terutama saat menjelang Pemilihan Kepala Desa (Pilkades).

Keamanan, kondisikeamanan diMadura termasuk labil dan rawan. Pendidikan mayoritas masyarakatnya yang rata-rata rendah merupakan penyebab utama mudahnya isuisu negatif menyebar luas dan mudahuntuk diadu domba. Selain itu ditunjang dengan politik desa yang kurang sehat, yaitu persaingan antar calonkepala desa yang sangat kuat menjelang Pilkades hingga Pilkades berikutnya, merupakan sarana peletus konflik yang sangat efektif.

Carok masal dapat sewaktu-waktu meletus tanpa ada media yang berani meliputnya. Kondisi demikian memaksa Klebun harus bertindak cepat dan memiliki peran koordinasi yang tinggi dengan pihak-pihak yang dapat memulihkan keadaan. Dalam hal ini, Gaya Kepemimpinan Situasional sangat diperlukan dalam meredam konflik ke arah masyarakat. Di sisi lain yang sangat penting untuk segera diterapkan adalah Gaya Kepemimpinan Birokratis yang efektif sehingga dalam berkoordinasi dengan pihak-pihak ber- kepentingan dapat terwujud suatu hubungan yang dapat meredakan situasi konflik dengan cara-cara yang tepat.

Kecamatan Robatal sebagai tingkat administratif terdekat yaitu setingkat diatas Klebun merupakan sarana yang cepat dan tepat untuk memberikan informasiterbaru bila konflik meletus. Namun personil keamanan ditingkat kecamatan memaksa mereka juga harus terus melakukan koordinasi intensif dengan pihak Kabupaten Sampang. Hal ini merupakan salah satu hambatan lamanya pemulihan situasi dan kondisi konflik khususnya dalam penerjunan aparat keamanan di lokasi kejadian.

Penyampaian informasi yang terlalu lama di lingkungan birokratis khususnya wilayah pemerintahan Kabupaten Sampang tersebut membuat Klebun harus menerapkan sistem gaya kepemimpinan yang efektif. Sehingga beliau menerapkan Gaya Kepemimpinan Birokratis yang tidak terlalu kaku, yaitu berjalan dengan fleksibel sesuai dengan situasi dan kondisi yang ada.

Seperti halnya dengan Gaya Kepemimpinan Birokratis, Gaya Kepemimpinan Situasional Efektif juga dapat digambarkan melalui serangkaian pendekatan dan wawancara dari para narasumber, yaitu mereka yang tersangkut paut langsung dalam interaksi dengan Klebun terutama dalam hal musyawarah untuk menentukan program-programbaik bantuan maupun pembangunan di wilayah Desa Torjunan. MakadalampengukuranEfektifitas Gaya Kepemimpinan Situasional Klebun Torjunan obyek yang diteliti adalahmasyarakat Desa Torjunan.

Agar pengukuran dapat dilakukan secara obyektif, maka obyek yang diambil adalah masyarakat yang aktif berinteraksi dengan Klebun. Secara mayoritas mereka adalah tokoh-tokoh masyarakat baik tokoh adat maupun tokoh agama. Namun demikian se- 
bagian dari mereka yang tidak pernah ikut berinteraksi juga dapat menggambarkan bagaimana langkah-langkah Klebun untuk menghadapi masyarakat yang kurang peduli terhadap pembangunan desanya. Selain itu mereka yang tidak pernah ikut dalam musyawarah ataupun berinteraksi dengan Klebun adalah suatu fenomena yang dapat menggambarkan bagaimana tingkat kesiapan masyarakat dalam berorganisasi khususnya di Desa Torjunan. Adapula masyarakat yang hanya bisa mengeluh bila program-program desa berjalan tidak sesuai dengan apa yang diharapkan baik berupa bantuan ataupun berupa pembangunan, namun mereka tidak turut memenuhi undangan dalam musyawarah. Mayoritas masyarakat hanya hadir ke rumah Klebun bila ada keperluan administrasi, seperti pembuatan KTP atau akta jual-beli dan keperluan administrasi yang lainnya.

Alasan yang dikemukakan oleh masyarakat yang 'kurang peduli' hampir sama, yaitu jarak antara rumahnya dengan rumah Klebun yang cukup jauh. Padahal bila ditelusuri lebih dalam, mereka mempunyai kendaraan berupa sepedamotor untuk menuju kerumah Klebun yang juga merupakan pusat pemerintahan desa. Adapula yang mengaku tidak mendapatkan undangan ketika musyawarah akan dilangsungkan. Padahal melalui wawancara dan pengamatan secara informal, Klebun telah mengundang atau memberitahu masyarakat mengenai program yang akan berjalan. Seperti program pembangunan kandang sapi, di mana Klebun telah memberitahu masyarakat mengenai pembangunan kandang sapi yang akan dibangun di Dusun Laok Leke. Tentunya pemberitahuan ini melaluiApel dari masing-masing dusun, namunketika peneliti melakukan wawancara dengan masyarakat sekitar Dusun LaokLeke adadi antaramereka yang tidak mengetahui mengenai pem- bangunan tersebut. Mayoritas dari mereka hanya mengetahui desas-desusnya saja sehingga tidak mengatahui secara pasti mengenai pembangunan tersebut.

Masyarakat dengan tipe seperti ini tidak dapat dijadikan sebagai obyek penelitian, walaupun dapat menggambarkan bagaimana Gaya Kepemimpinan Situasional Klebun Torjunan khususnya dalam menghadapi masyarakat yang seperti itu. Hal ini dikarenakan mereka jarang berinteraksi dengan Klebun sehingga mereka kurang mengetahui, bahkan tidak memahami bagaimana Gaya Kepemimpinan Klebun dan apa saja upaya Klebun untuk memajukan desanya, hanya mereka tahu bahwa beberapa pembangunan baik fisik (contoh: pembangunankandang sapi) maupun nonfisik (contoh: bantuan raskindan BLT) sudah mereka terima dan mereka rasakan.

Berdasarkan hasil penelitian, perilaku masyarakat yang demikian bukan karena Klebun yang tidak peduli terhadap masyarakatnya, namun justru sebaliknya. Menurut informasi dari masyarakat yang aktif berinteraksi dengan Klebun dan juga tokoh-tokoh masyarakat Desa Torjunan, Klebun sudah melakukan pendekatan terhadap mereka, bahkan terhadap lawan politiknya sekalipun. Namun karena mereka tetap tidak mau peduli, maka Klebun dan tokoh masyarakat membiarkannya. Langkah ini ditempuh bukan karena Klebun sudah membenci masyarakat dengan tipe seperti ini, namun hal ini dilakukan untuk meminimalisir resiko dan pecahnya konflik sosial.

Ketidakpedulian sebagian besar masyarakat bukan karena murni dari diri mereka sendiri, namun salah satu faktornya adalah rendahnya pendidikan, pengetahuan yang kurang serta kondisi politik desa yang cukup kuat, sebagaimana telah dijelaskan pada paparan sebelumnya. Ketidakpedulian masyara- 
kat inilah yang merupakan faktor utama pentingnya mencariEfektifitas Gaya Kepemimpinan Situasional Klebun Torjunan.

Gambaran Klebun yang telah melakukan berbagai pendekatan secara individual, kekeluargaan dan secara politis, namun mereka tetap pada pendiriannya merupakan suatu fenomena yang cukup menggambarkan sekilas gaya kepemimpinan Klebun Torjunan dalam memimpin masyarakatnya. Hanya saja judul dari penelitian ini terkait dengan aktivitas roda pemerintahan dan bukan pendekatan secara psikologis masyarakat, maka deskripsi dalam penelitian ini mengacu pada bagaimana interaksi Klebun Torjunan dalam bermusyawarah dengan warganya yang turut andil membangunDesa Torjunan. Darimusyawarah atau yang biasa dikenal dengan istilah MusyawarahRencana Pembangunan Wilayah Desa (Musrenbangdes) inilah Efektifitas Gaya Kepemimpinan Situasional Klebun Torjunan dapat digambarkan secara lebih terukur melalui teknik pengukuran yang dikemukakan oleh Hersey \& Blanchard.

Gaya kepemimpinan Klebun Torjunan yang dinilai sebagian besar masyarakat demokratis dan luwes (situasional), merupakan sebuah kemajuan besar bagi masyarakat Desa Torjunan, sebab selama \pm 24 tahun telah dipimpin oleh seorang Klebun yang dinilai oleh sebagian besar masyarakat sebagai pemimpin yang diktator dan penuh dengan ambisi kekuasaan. Hal ini sesuai dengan pernyataan masyarakat pada lembar wawancara.

Sampaipenelitian iniditulis, terjangan dan ancaman Klebun lama terhadap Klebun yang saat ini menjabat masih tetap dirasakan, baik oleh Klebun sendiri maupun oleh masyarakat luas bahkan hal ini dirasakan hingga wilayah kecamatan. Masyarakat telah menyadari hal ini dan konflik pun sudah pernah akan terjadi, namun pendekatan dengan ber- bagai pihak yang dimediasi oleh Klebun maupun pihak kecamatan dapat meredakan konflik tersebut, sehingga carok pun dapat dihindari.

Dari gambaran hasil wawancara terhadap masyarakat dapat diketahui bagaimana Gaya Kepemimpinan Situasional Klebun terhadap masyarakat Desa Torjunan khususnya dalam menghadapi gesekan-gesekan dengan lawan politik mereka yang secara langsung atau tidak dapat berimbas pada gejolak sosial. Dalamhasil wawancara dengan masyarakat telah dipaparkan contoh-contoh gesekan dengan lawan politik yang dapat menyebabkan terganggunya pembangunan desa. Salah satunya adalah pembangunan jalan di Wilayah TimurkhususnyadiDusunSendang Desa Torjunan, di mana sebagian masyarakatnya tidak setuju setelah mereka menandatangani surat perjanjian. Setelah ditelusuri baik oleh Klebun, pihak Kecamatan, Pihak kepolisian, Babinsa dan pihak Kabupaten Sampang memang terdapat indikasi politik yang kurang sehat. Selain itu proses raskin yang dilaporkan menyalahi prosedur oleh lawan politik Klebun terpilih menyebabkan sistem pemerintahan sempat terhambat. Klebun harus memenuhi undangan kepolisian untuk memberikan keterangan yang sebenarnya. Namun karena saksi dari masyarakat yang kuat, bahwa Klebun tidak bersalah maka beliau dapat dibebaskan. Dalam pernyataannya, SerdaArul sebagai Barikade Pengamanan Desa juga menyatakan bahwa hal itu termasuk gesekan politis untuk menjebak Klebun agar pemilihan di masa mendatang tidak terpilih kembali.

Kondisi ini merupakan fenomena politis yang dapat menggambarkan tantangan serta hambatan Klebun Torjunan dalam memimpin masyarakatnya. Untuk mengetahui Efektifitas Gaya Kepemimpinan Situasional yang saat ini diterapkan khsususnya dalam meng- 
hadapi gejolak politik desa di tengah-tengah tanggungjawabnya sebagaipemimpin dan pengayom masyarakat, maka dalam penelitian ini perlu gambaran yang lebih rinci dan tertimbang. Gambaran ini dapat diwujudkan dengan penyesuaian antara fenomena yang digambarkan oleh para narasumber dengan grand theory yang dikemukakan oleh Hersey \& Blanchard.

Hersey \& Blanchard membuat suatu instrumen yang dapat mengukur apa jenis Gaya Kepemimpinan Situasional yang efektif untuk diterapkan, dalam penelitian ini khususnya adalah diDesa Torjunan. Instrumen tersebut terdiri atas 12 poin pertanyaan. Namun pada poin pertanyaan nomor 12 yang menyangkut tentang konflik serta ketidakharmonisan, maka dalam penelitian inikhusus untuk nomor 12 dengan tipe wawancara terhadap masyarakat jawaban disamaratakan.

Beberapa alasan yang dapat dikemukakan untuk menjelaskan pernyataan di atas adalah: 1. Bahwa bila pertanyaan nomor $12 \mathrm{ini}$ dikemukakan pada masyarakat dapat membuka luka lama yang telah terpendam dan dikhawatirkan akan timbul ketidakharmonisan antar masyarakat atau konflik akan meletus kembali. Karena hal yang sensitif inilah, maka untuk poin pertanyaan nomor 12 hanya diambil satu sampel jawaban, sebagai informan adalah tokoh agama yang lebih memahami tentang kondisi masyarakat secara luas. Beliau juga memberikan nasehat agar pertanyaan tentang konflik tidak dilontarkan kepada masyarakat, karena dikhawatirkan mereka akan berpikir hal-hal yang tidak diinginkan;2) Penyelesaian permasalahan konflik di Madura memiliki cara yang berbeda dengan di daerah lain. Selain itu permasalahan yang diungkit kembali bisa cepat meledak dan penyelesaiannya dapat diselesaikan dengan cara-cara mereka sendiri. Me- ngingat mayoritas pendidikan masyarakat yang rendah dan watak yang keras, maka pertanyaan nomor 12 ini merupakan pertanyaan yang krusial, akan tetapi dalam instrumen yang dikemukakan Hersey \& Blanchard pertanyaan ini merupakan kunciutama untuk dapat mengukur Efektifitas Gaya Kepemimpinan Situasional. Maka untuk jawaban pertanyaan nomor 12 tetap dicantumkan dengan permisalan yang sama antar semua masyarakat; 3) Dari sampel jawaban yang didapat, terkdang masyarakat Madura masih menyelesaikan konflik mereka dengan cara adat. Salah satu adat yang kini masih dipertahankan oleh sebagian masyarakatnya adalah carok dan pembalasan dendam bagi keluarga yang dibunuh saat konflik terjadi, walaupun saat ini carok sudah jauh berkurang daripada beberapa tahun yang lalu. Menimbang situasi tersebut maka, bila pertanyaan nomor 12 dalam instrumen Hersey \& Blanchard dipaksa untuk dikemukakan di masyarakat akan menimbulkan resiko yang tinggi dan dapat berakibat fatal. Itulah beberapa alasan penelitian ini menyamaratakan jawaban yang menyangkut pertanyaan nomor 12 .

Untuk menggambarkan lebih detail Gaya Kepemimpinan Situasional Klebun Torjunan, maka dalam penelitian ini dicantumkan narasumber dari masyarakat dariDesa Torjunan yang bergerak di beberapa bidang keilmuan yang menangani kesejahteraan masyarakat seperti bidang kesehatan, bidang pertanian, dan bidang keamanan.

Bidang pertanianmerupakan bidang yang sangat penting untuk digambarkan mengingat masyarakat Desa Torjunan mayoritas adalah para petani, sehingga sebagian besar kebutuhan hidup mereka adalah dari hasil cocok tanam. Namun pada hasil wawancara dengan salah satu anggota Badan Pengawas Desa (BPD) yang juga merupakan penyalur 
bantuan pertanian dari pemerintah Kabupaten Sampang didapatkan informasi bahwa Klebun masih sangat kurang dalam pengembangan pembangunan bidang pertanian. Kelangkaan pupuk yang terjadi beberapa waktu lalu belum mendapatkan respon Klebun untuk tahunsekarang. Klebun yakin bahwa kelangkaan pupuk tidak akan terjadi, dan seandainya terjadi Klebun tidak akan banyak menangani kecuali ada laporan dari masyarakat. Musyawarah dengan masyarakat yang menyangkut peningkatan program pertanian pun tidak pernah dilakukan, begitupula dengan penyuluhan. Narasumber menyatakan sendiri bahwa saat ini Klebun masih belum mampu mengembangkan pembangunan dibidang pertanian, sehingga masyarakat kurang mendapatkan hasil yang maksimal dalam memanen hasil buminya. Namun, narasumber memiliki harapan positif untuk ke depannya, karena Klebun yang sekarang dekat dengan masyarakat. Sehingga dapat diperkirakan bila kedepan ada keluhan dari masyarakat Klebun cepat tanggap dalam mengatasi kesulitan mereka. Walaupun demikian, permasalahan paling pelik yang saat ini tidak dapat ditangani baik oleh Klebun, pihak Kecamatan Robatal, maupun Kabupaten Sampang bahkan dari IPB adalah permasalahan kelangkaan sumber air. Karena memang Desa Torjunan merupakan desa yang kering dan sulit didapatkan sumber air.

Adapun faktor kesehatan dan kebersihan merupakan faktor yang belum dapat ditingkatkan kualitasnya baik oleh Klebun maupun oleh masyarakat pada umumnya. Pembuangan sampah secara sembarangan, MCKdi DAM tadah hujan yang tidak mengalir merupakan suatu hal yang biasa. Klebun pun tidak pernah mengusulkan bantuan kesehatan. Akan tetapi program posyandu dari Poliklinik Desa dan Kabupaten Sampang te- rus diupayakan baik oleh Klebun maupun pemerintah Kecamatan Robatal. Perluasan DAM dan pengerukanEmbung menjadiagenda utama dalam program pembangunan beberapa tahun mendatang. Hal ini dinyatakan dalam Musrenbangcamyang akan dicantumkan dalamlembar lampiran 5.

Faktor yang paling penting adalah faktor keamanan, mengingat situasi dan kondisi di Madura pada umumnya dan di Desa Torjunan pada khususnya. Faktor ini merupakan salah satu faktor yang efektif untuk menggambarkan Gaya Kepemimpinan Situasional Klebun Torjunan kepada masyarakatnya.

Untuk mendapatkan gambaran dan informasi yang lebih lengkap tentang faktor keamanan ini, maka wawancara dilakukan dengan TNI yang ditugaskan sebagai Barikade Pembina Desa atau Babinsa di Desa Torjunan. Dari wawancara dan diskusidengan Beliau, didapatkan banyak sekali informasi yang berkaitan dengan Poleksosbud Hankam masyarakat Desa Torjunan. Gambaran ini dapat dilihat kembali pada sub bab 4.3.

Gambaran tertimbang Gaya Kepemimpinan Birokratis Klebun Torjunan adalah suatu deskripsi tentang bagaimana Gaya Kepemimpinan Birokratis Klebun Torjunan dilihat dari sudut teori yang telah dikemukakan oleh para ilmuwan. Tujuannya adalah untuk melihat tingkat keefektifan Gaya Kepemimpinan Birokratis Klebun Torjunan yang saat ini diterapkan, khususnya menyangkut peranannya sebagai bagian dari sistem pemerintahan yang berperan penting untuk memediasi antara masyarakat Desa Torjunan dengan pemerintah Kecamatan Robatal.

Untuk mengetahui bagaimana tingkat efektifitas Gaya Kepemimpinan Klebun Torjunan, maka diperlukan suatu instrumenkendali yang telah disesuaikan dengan kondisi yang 
ada diDesa Torjunan. Instrumen kendali iniberfungsi sebagai pengarah utama untuk mengarahkan jawaban terbuka dari para responden kepada jawaban tertutup sesuai pilihan yang dikemukakan oleh Reddin di mana pilihan ini telahdimodifikasisedemikian rupa hingga sesuai dengan kondisi yang ada di Desa Torjunan. Hal ini dilakukan agar jawabanjawaban dari responden yang sarat dengan informasi dapat diukur dan ditimbang sesuaidengan langkah-langkah pengukuran yang telah ditetapkan. Instrumenkendali akan ditampilkan dalam penelitian ini pada Bab Lampiran.

Karena yang banyak terlibat dalam aktivitas birokratis adalah Klebun Desa Torjunan dengan Camat dan Kepala Bidang yang ada di Kecamatan Robatal, maka untuk responden yang dipilih serta diukur adalah Klebun Desa Torjunan, Camat, dan Kepala Bidang yang ada di Kecamatan Robatal saja.

Beberapa langkah yang diperlukan agar efektifitas Gaya Kepemimpinan Birokratis Klebun Torjunan dapat diukur, yaitu:

Langkah pertama adalah Penyesuaian (Sinkronisasi), Langahinimerupakan langkah awal untuk melakukan pengukuran. Langkah ini adalah menyesuaikan antara informasi-informasi terbuka yang disampaikan oleh para responden dengan instrumen kendali agar mendapatkan jawaban yang dapat diukur.

Langkah kedua input data, Langkah ini adalah langkah lanjutan dari langkah sinkronisasi. Di mana hasil informasi tertimbang dimasukkan dalam suatu kolom khusus yang telah disediakan. Kolom ini merupakan kolomukur yang memiliki angka-angka tertentu sebagai ukuran tingkat efektifitas Gaya Kepemimpinan Klebun Torjunan yang saat ini diterapkan.

Jawaban dalam kolom ini merupakan jawaban tertimbang per responden yang ter- diri atas 12 pertanyaan. Dari 12 pertanyaan tersebut tiap kolom pada kunci data tertimbang merupakan standar baku jawaban yang nilainya telah ditentukan. Sebagai contoh kolom a, dikalikan dengan angka -2 (minus dua); b dikalikan dengan angka -1 (minus satu); c dikalikan dengan angka +1 (plus satu); dan d dikalikan dengan angka +2 (plus dua).

Jawaban tertimbang para responden akan dicetak dalam huruf tebal. Sehingga, semisal jawaban tertimbang Camat Robatal pada poin pertanyaan nomor satu adalah A, maka ia berada pada kolom d (lihat kolom di bawah). Maka jawaban Adicetak tebal (Bold) dan jawaban ini dikalikan +2 (plus dua). Masing-masing kolom bernilai +1 (plus satu), sehingga kolom a, b, c dan d bernilai +1 dan dikalikan dengan nilai pengali pada masingmasing kolom.

Kemudian jawabanA, B, C dan D, masing-masing dijumlah dalam kolom penjumlah dan dikalikan dalam kolom penimbang. Hasil kali merupakan hasil tertimbang kotor dari salah seorang responden.

Langkah ketiga, Nilai Rata-Rata (Mean), nilai rata-rata merupakan nilai untuk menentukan rata-rata tingkat efektifitas Gaya Kepemimpinan Birokratis Klebun Torjunan dari tiap responden. Nilai ini berfungsi untuk menggambarkan secara akumulatiftingkat efektifitas Gaya Kepemimpinan Birokratis Klebun Torjunan.

Bila nilai tersebut dimasukkan ke dalam teori efektifitas Gaya Kepemimpinan Birokratis Reddin, dapat digambarkan pada gambar 1.

Dari pengukuran rata-rata nilai tertimbang tersebut dapat diketahui, bahwa tingkat efektifitas Gaya Kepemimpinan Birokratis Klebun Torjunan berada pada level $-3,2$ (minus tiga koma dua). Nilai ini hampir 
mendekati titik keseimbangan antara gaya yang kurang luwes dengan gaya yang luwes.

Bila dipandang secara fenomenologi, tingkat efektifitas yang ditunjukkan merupakan suatu hal yang logis. Sebab Klebun merupakan lembaga pemerintahan yang berfungsi sebagai mediasi antara pemerintah di atasnya yaitu Kecamatan dan Kabupaten dengan masyarakat desanya.

Hubungan formal secara birokratis, memang harus merujuk pada aturan-aturan yang berlaku. Perangkat pemerintahan baik Kabupaten, Kecamatan terlebih Klebun tidak bisa berbuat apapun bila berhadapan dengan permasalahan administratif dalam sistem birokratis. Di sisi lain, Klebun sebagai pengayom masyarakat harus memberikan keluwesan dalambidang-bidang tertentu. Ke- luwesan ini akan dapat diwujudkan bila peraturan daerah ataupun undang-undang membolehkannya. Adapun di luar ketentuan dalam peraturan daerah dan undang-undang, maka hal tersebut dapat dimusyawarahkan.

Sebagai contoh yang paling menonjol dalam permasalahan administrasi adalah permasalahan pernikahan. Adat di Madura pada umumnya termasuk pula di Desa Torjunan pada khususnya, menikah dibawah umur adalah hal yang biasa. Sebab mereka memegang teguh kepada aturan Agama Islam yang menganjurkan para pemuda/i untuk menikah bila telah mampu menikah, dan mayoritas mereka bila telah dipinang oleh seseorang laki-laki yang siap untuk menikahinya hal itu merupakan indikasi bahwa rumah tangga sudah siap untuk dibangun. Di sisi lain Undang-

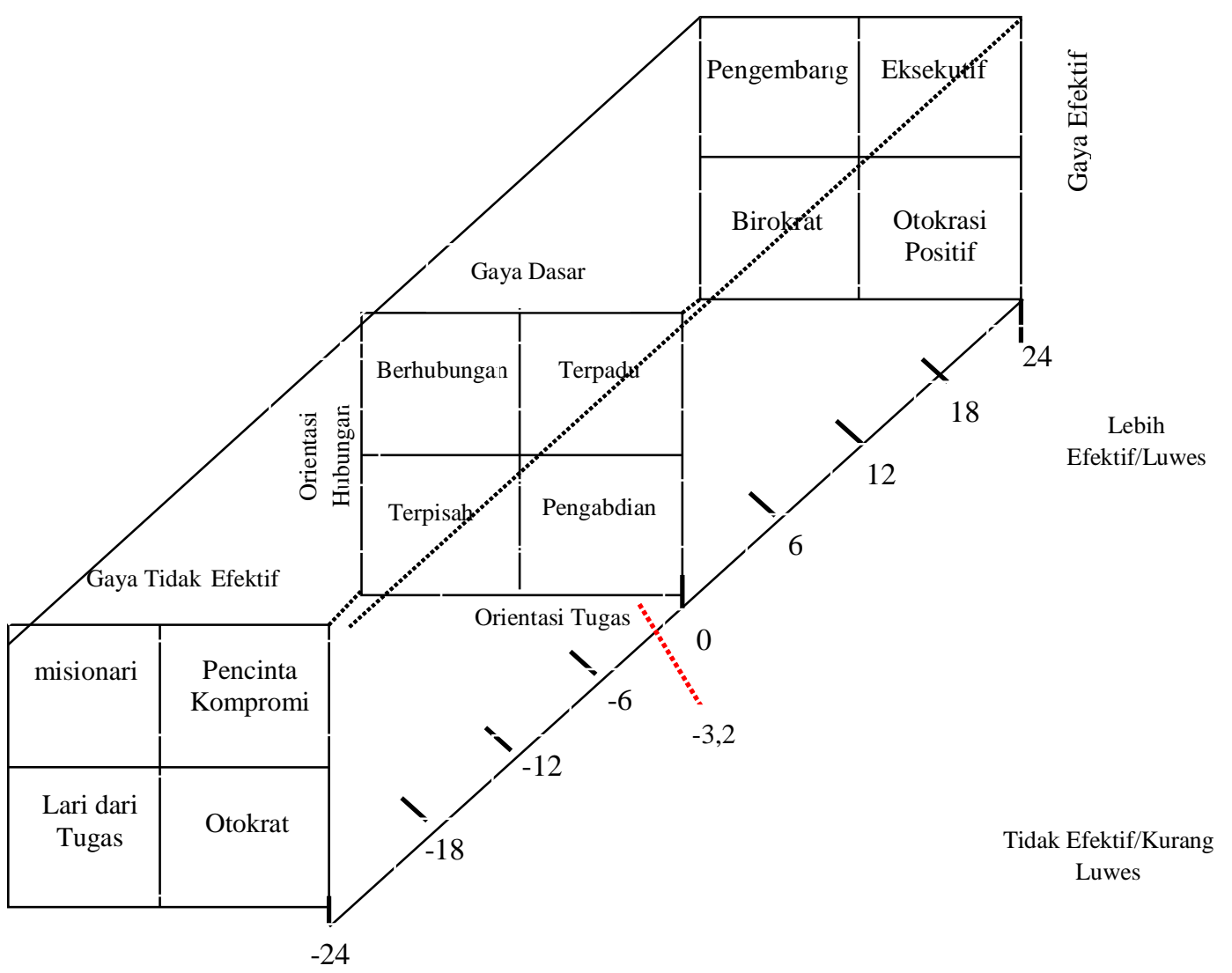

Gambar 1. Tingkat Efektifitas Gaya Kepemimpinan Birokratis Klebun Torjunan 
Undang Republik Indonesia yang mengatur tentang pernikahan, mewajibkan Warga Negara Indonesia menikah dengan ketentuan usia minimal, yaitu 21 Tahun untuk laki-laki dan 18 tahun untuk wanita. Aturanini tidak banyak diperhatikan oleh masyarakat bahkan bertambah hari bertambah banyak dari mereka yang menikah di usia dini sehingga menimbulkan masalah administrasi, khususnya dalampembuatan Kartu Keluarga danAkta Kelahiran anaknya.

Klebun sebagai pemimpin desa yang merupakan bagian dari lembaga pemerintahan Negara Republik Indonesia di tingkat daerahkhususnya wilayah Desa Torjunan harus tunduk dan patuh terhadap undang-undang yang berlaku di Wilayah Negara Kesatuan Republik Indonesia (NKRI). Di sisi yang lain, Klebun sebagai orang yang ditunjuk dan dipercaya masyarakat melalui Pemilihan Kepala Desa (Pilkades) diharuskan dapat melindungi dan mengayomi masyarakat, sehingga kebijaksanaan harus dapat diterapkan secara efektif dalam memimpin masyarakatnya. Di sisi yang lainnya lagi, sebagian besar masyarakat Madura pada umumnya memiliki watak yang keras dan kemauan yang kuat, tak jarang konflik masyarakat sering timbul akibat gesekan-gesekan sosial. Maka disinilah peran Klebun secara birokratis, yaitu peran yang sangat penting untuk menjalankan roda pemerintahan khususnya dalam memanajemen roda pemerintahan secara formal menurut undang-undang dan adminstrasi secara birokratis. Peran ini kemudian memunculkan sekumpulan cirikhas yang dimiliki seorang pemimpin untuk mempengaruhi bawahan agar tujuan untuk menjalankan roda pemerintahan dapat tercapai. Untuk itu diperlukan manajemen yang baik untuk memfungsikan Gaya Kepemimpinan Birokratis yang efektif khususnya dalam pendekatan kepada pemerintahan fungsional di atasnya.
Bentuk efektifitas Gaya Kepeimpinan Birokratis yang dapat ditunjukkan dalam gambaran fenomenologi menurut hasil wawancara dengan para narasumber adalah, pendekatan Klebun Torjunan kepada masyarakatnya. Pendekatan ini dilakukan secara kekeluargaan untuk dapat memberikan pemahaman dan pengertian kepada masyarakat mengenai pentingnya melakukan suatu tindakan sesuai dengan undang-undang yang berlaku. Pendekatan inidilakukan secara luwes, dalam arti tidak memaksakan kehendak masyarakat yang akan melangsungkan pernikahan dibawahumur. Mengenai resiko tidak mendapatkan surat nikah, adalah resiko yang ditanggung secara pribadi sebab Klebun sudah bertanggungjawabuntuk menjelaskan secara terang mengenai pentingnya berjalan sesuai undang-undang dan resiko yang dihadapinya.

Sehingga permasalahan ini bila ditinjau dari sudut efektifitas Gaya Kepemimpinan Birokratis dalam diri Klebun Torjunan adalah, bahwa Klebun tetap tidak dapat merubah ketentuan administrasi birokratis yang telah berlaku, terlebih sudah diatur dalam undang-undang yang sah. Klebun hanya dapat memberikan pemahaman dan pengertian kepada masyarakat serta kebebasan untuk kepada masyarakat untuk melakukan tindakan yang akan mereka lakukan. Maka dari itu dalamhasil penelitian yang digambarkan secara tertimbang, angka yang menunjukkan -3,2 tidak dapat secara langsung divonis bahwa Gaya Kepemimpinan Birokratis Klebun Torjunan dalammemanajemen roda pemerintahan penerapannya tidak efektif, walaupunmemang secara teoritis dapat dinyatakan sepertiitu. Halinilah yang menjadi ciri khas penelitian secara deskriptif kualitatif, yaitu mengambarkan secara detail obyek yang ditelitiuntuk dijelaskan kepada pihak-pihak yang membutuhkan manfaat pene- 
Efektifitas Gaya Kepemimpinan dalam Memanajemen.... (Arnanda Ajisaputra)

litian sesuai dengan tujuan penelitian yang telah ditetapkan.

Oleh karena itu dalam penelitian ini digambarkan secara detail, baik secara fenomenologis maupun secara tertimbang menurut grand theory Gaya Kepemimpinan Klebun Torjunan yang efektifuntuk diterapkan diDesa Torjunan dalam memanajemen roda pemerintahan desa. Untuk penilaian dan keputusan akhir tergantung dari pemahaman, wawasan, serta sudut pandang masing-masing pembaca.

Sebagai pengayommasyarakat khususnya di Desa Torjunan, maka Klebun Torjunan harus mampu berinteraksi dengan masyarakat, harus mampu memahami kebutuhan mereka sekaligus melayaninyaserta harus mampu melindungi mereka dari baik dari segi sosial maupun kemanan.

Untuk itu cirikhas kepemimpinan yang dapat mempengaruhi masyarakat Desa Torjunan sangat penting dibutuhkan untuk suatu pendekatan kepada masyarakat dalam mencapai tujuan pemerintah desa, yaitu menjadikan Desa Torjunan sebagai desa yang aman, tentram dan sejahtera. Sehingga Gaya Kepemimpinan Situasional yang efektif untuk diterapkan Klebun dalam memanajemen roda pemerintahan khususnya dalam segi hubungan denganmasyarakat Desa Torjunan sangat dibutuhkan. Efektifitas ini dapat digambarkan secara lebih akurat dan tertimbang bila dicocokkan dengan grand theory yang dikemukakan olehHersey \& Blanchard.

Beberapa langkah yang diperlukan agar efektifitas Gaya Kepemimpinan Situasional Klebun Torjunan dapat digambarkan, yaitu:

Langkah pertama adalah Penyesuaian (Sinkronisasi), langkah ini merupakan langkah awal sebelummelakukan deskripsi Gaya Kepemimpinan Situasional Klebun Torjunan yang efektifuntuk diterapkan. Langkah ini menyesuaikan antara informasi-informasi terbuka yang disampaikan oleh para responden dengan instrumen kendali agar mendapatkan jawaban yang dapat diukur.

Langkah ketiga adalahinput data, langkah ini adalah langkah lanjutan dari langkah sinkronisasi. Di mana hasil informasi tertimbang dimasukkan dalam suatu kolom khusus yang telah disediakan. Kolom ini merupakan kolom yang disediakan untuk dapat memilih Gaya Kepemimpinan Situasional yang efektif untuk diterapkan oleh Klebun Torjunan dalam memanajemen roda pemerintahan khususnya dalam mengatur dan mengayomi masyarakatnya.

Langkah selanjutnya, untuk dapat menentukan Gaya Kepemimpinan Situasional yang efektif diterapkan adalah dengan cara memasukkan jawaban tertimbang per responden ke dalamkolomyang telah disediakan dengan cara memberikan nomor pada masing-masing kolom sesuaidengan poin pertanyaan yang ada. Agar jawaban tertimbang per responden dapat dimasukkan ke dalam kolom yang tepat maka harus disesuaikan dengan kuncijawaban yang telah tersedia. Selanjutnya jawaban per responden diberi tanda tebal (bold).

Langkah selanjutnya adalah memasukkan jawaban tertimbang masing-masing responden yang telah diproses dalamkolomkunci jawaban ke dalam kolom Hersey \& Blanchard.

Kolom Hersey \& Blanchard mempunyai empat bidang persegi. Masing-masing bidang itu memilikinama yaitu mulai dari kanan bawah menuju kiri bawah berlawanan arah jarum jam adalah Kolom Instruksi (G-- $)$; Kolom Konsultasi $\left(\mathrm{G}_{2}\right)$; Kolom Partisipasi $\left(\mathrm{G}_{3}\right)$; Kolom Delegasi $\left(\mathrm{G}_{4}\right)$. Masing-masing kolom mempunyai ciri-ciri tersendiri yang telah dijelaskan dalam Bab II.

Kolom tersebut akandiisi oleh nomor pin jawaban para responden. Sebagai contohresponden I memiliki jawaban tertimbang B 
pada poin pertanyaan 1 (satu). Pada kuncijawaban jawaban B pada pertanyaan nomor satu terletak di kolom alternatif tindakan nomor 3 (tiga). Maka dalamkolom Hersey \& Blanchard nomor 1 (satu) akan ditulis dalam kolom $\mathrm{G}_{3} /$ Kolom Partisipasi. Kolom yang paling banyak diisinomor jawaban akan ditandai dengan huruf tebal, hal ini berarti kolom tersebut adalah kolom mayoritas yang dipilih. Selanjutnya kolom mayoritas merupakan kolom yang berfungsi untuk menghasilkan gambaran tindakan efektif Gaya Kepemimpinan Situasional Klebun Torjunan secara akumulatif. Hal ini berlaku untuk nomor seterusnya dan pada semua responden yang terdiriatas masyarakat Desa Torjunan serta Klebun Torjunan.

Kolom Akumulatif merupakan kolom yang berfungsiuntuk mengakumulasikan jawaban tertimbang yang telah diklasifikasikan dalam KolomEfektifitas Tindakan. Dari kolom akumulatif tersebut dapat diketahui gambaran secara lebih akurat tindakan yang efektif diterapkan oleh Klebun Torjunan khususnya dalam menerapkan efektifitas Gaya Kepemimpinan Situasional khususnya dalam memanajemen roda pemerintahan Desa Torjunan.

Bentuk KolomAkumulatif sama dengan KolomEfektifitas Tindakan, yang menjadiperbedaannya adalah jawaban yang diinput adalah total responden. Mayoritas kolom jawaban responden dimasukkan ke dalam Kolom Akumulatif. Sebagai contoh responden pertama mayoritas jawaban terletak pada kolom $\mathrm{G}_{2}$, maka dalam Kolom Akumulatif $\mathrm{G}_{2}$ ditulis nomor responden. Kemudian mayoritas $\mathrm{G}_{2}$ juga terdapat pada responden keenam. Sehingga $\mathrm{G}_{2}$ terdapat dua responden, yaitu responden pertama dan keenam. Jumlah kolom terbanyak yang terisi responden merupakan hasil tindakan yang efektif untuk diterapkan.

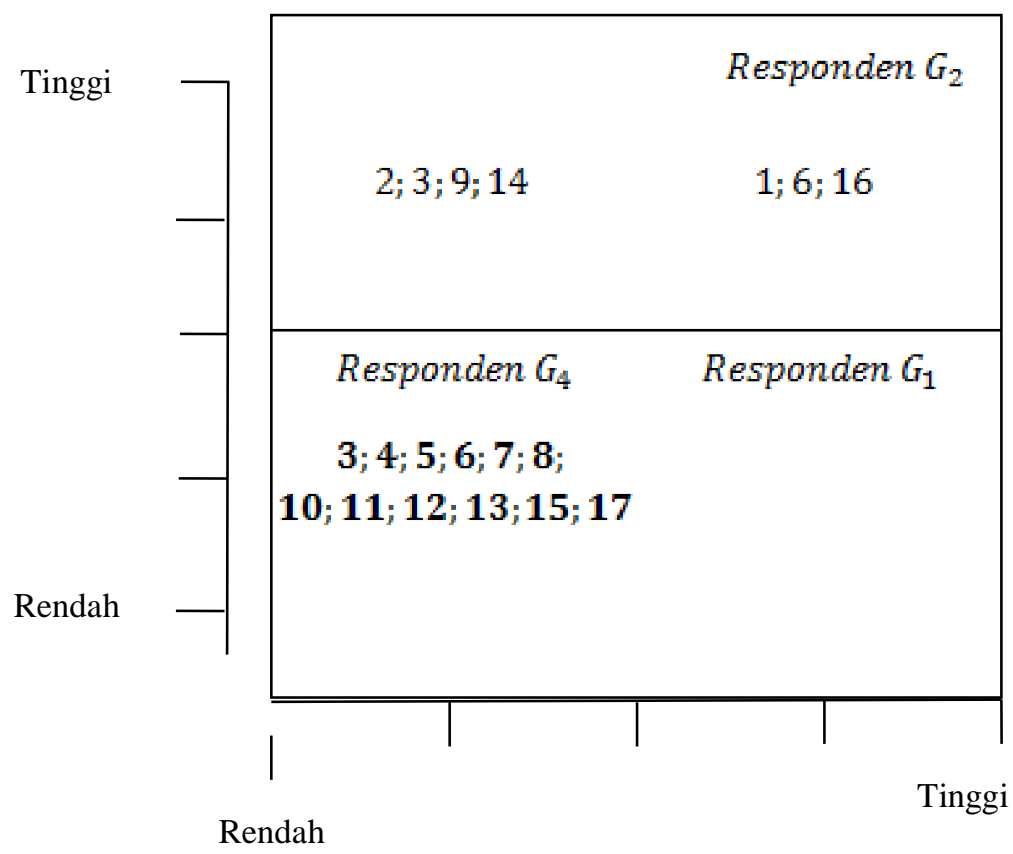

Gambar 2. Tindakan Efektif Dalam Gaya Kepemimpinan Situasional 
Proses input datake dalam KolomAkumulatif digambarkan pada gambar 2.

Setelah melalui beberapa tahapan, dapat diketahui lebih akurat bahwa tindakan yang efektif diterapkan Klebun Torjunan untuk mewujudkanEfektifitas Gaya Kepemimpinan Situasional khususnya dalam memimpin dan mengayomi masyarakat adalah tindakan Delegating yang dapat dilihat pada Kolom $\mathrm{G}_{4}$. Dalam Teori Hersey \& Blanchard dinyatakan bahwa Delegating $/ \mathrm{G}_{4-}$ adalah kondisi di mana seorang pemimpin melimpahkan pembuatan keputusan dan pelaksanaan kepada bawahan. Kolom ini juga menggambarkan rendahnya hubungan antara pemimpin denganyang dipimpin sertarendahnya pemberian tugas kepada orang-orang yang dipimpinnya.

Hersey \& Blanchard juga menyatakan bahwa, apabila mayoritas jawaban berada padakolom $\mathrm{G}_{4}$, berarti tingkat kematangan yang dipimpin oleh seorang pemimpin mencapai tingkat kematangan yang tinggi. Secara deskriptif tindakanorang-orang yang dipimpinadalah mereka telah mampu dan mau melaksanakan tugas dan pekerjaan secara mandiri dengan inisiatif yang tinggi.

Hasil yang dikemukakan berdasarkan teoriHersey \& Blanchard tersebut, bila diterapkan pada obyek penelitian, yaitu Klebun Torjunan serta masyarakatnya tidaklah dapat serta merta diputuskan demikian. Secara fenomenologi, seperti apa yang telah tergambar dalam hasil wawancara dengan para responden dinyatakan bahwa, masyarakat masih sangat rendah pendidikannya dan mereka banyak sekali yang tidak mempedulikan pembangunan di desanya. Hanya saja mereka sangat tidak senang dan menuntut bila manfaat pembangunan itu tidak sampai pada mereka.

Sehingga teori yang dinyatakan oleh Hersey \& Blanchard tidak dapat dibenarkan seratus prosen akan tetapi juga tidak dapat disalahkan seratus persen. Secara fenomenologis, Klebun Torjunan memang menggantungkan sebagian besar keputusannya kepada masyarakat Desa Torjunan. Sehingga merekalah yang seringkali memutuskan penerapan pembangunan sesuai dengan keinginan mereka. Kepala Desa/Klebun yang menggantungkan sebagian besar keputusannya kepada masyarakat bukan berarti dapat langsung disimpulkan bahwa masyarakat memiliki inisiatif yang tinggi serta dapat melakukan pekerjaan secara mandiri.

Gambaranmasyarakat yang tampak pada hasil wawancara dengan mereka dapat diketahui bahwa masyarakat masih belum dapat diajak berfikir mandiri, mereka banyak menggantungkan program-program pembangunan dari pemerintah. Selama ini Desa Torjunan belum dapat membangun desanya sendiri dengan biaya swadaya, namun dengan danadana bantuan yang diberikan oleh pemerintah baik tingkat kabupaten, propinsi, maupun pemerintah pusat. Klebun yang memberikan keputusan berdasarkan keinginan masyarakat adalah bukan semata-mata karena mereka memiliki programyang diusulkan kepada Klebun untuk diterapkan di desanya. Peran Klebun adalah memberitahukan program-program pembangunan maupun peningkatan kesejahteraan masyarakat dari pemerintah. Selanjutnya, Klebun meminta pendapat masyarakat mengenai persetujuan mereka. Apabila masyarakat tidak setuju, maka program akan dihentikan atau dialihkan dan apabila masyarakat setuju, maka programakan disesuaikan dengan keinginan masyarakat. Dari pendapat masyarakat inilah, Klebun akan menyampaikan keinginan masyarakat kepada pemerintahyang mencetuskan program danmendanainya. Informasi dari Klebun ini sangat penting sekaliuntuk pelaksanaan program pembangunan, yaitu agar pelaksanaannya berjalan dengan lancar, dapat diterima masya- 
Ekonomika-Bisnis Vol. 5 No.1 Bulan Januari Tahun 2014. Hal 23-44

rakat, serta tidak mengalami kerugian karena ditentang atau dirusak oleh masyarakat.

Tempramen yang keras merupakan salah satu pertimbangan Klebun untuk bersikap hati-hati dan tidak terlalu memaksakan kehendaknya. Konflik intern dalam satu desa bahkan antar desa bisa terjadi bila masyarakat ditekan dengan harus menyetujui pendapatnya. Maka bila memiliki keinginan dan cita-cita kuat untuk mensejahterakan masyarakatnya seorang Klebun harus melakukan pendekatan sosial dengan masyarakat yaitu dengan cara sering mengadakan musyawarah bersama membahas soal pelaksanaan pembangunan yang diharapkan oleh masyarakat. Permasalahan teknis pembangunan adalah hak daripada pemerintah atau perusahaan yang menangani pembangunan itu. Sehingga pada intinya Klebun melaksanakan musyawarah dalammembahas program-program pembangunan dan peningkatan kesejahteraan dengan masyarakat adalah agar programprogram tersebut dapat diterima masyarakat sehingga konflik baik yang ringan maupun yang dapat menimbulkan perkelahian dapat dicegah. Bila masyarakat telah mengetahui adanya program pembangunan yang sesuai dengan keinginan mereka dan Klebun pun mendukung keptutusan mereka, maka pelaksanaan program-program itu dimungkinkan akan berjalan tanpa menyebabkan konflik yang besar. Seandainya konflik terjadi karena suatu hal, maka semua masyarakat akan berupaya membantu Klebun serta pemerintah untuk menjalankan program itu kembali berjalan, karena mayoritas masyarakat Desa Torjunan yakin, bahwa permasalahan yang datang di saat program yang telah disetujuimasyarakat berlangsung, maka itu adalah ulah dari sekelompok orang yang ingin memperburuk citra pemimpin mereka.

\section{Penutup}

Dari keseluruhan pembahasan pada bab sebelumnya, maka dapat ditarik kesimpulan sebagai berikut: Efektifitas Gaya Kepemimpinan Birokratis Klebun (Kepala Desa) Torjunan Kabupaten Sampang terhadap laju roda pemerintahan Masyarakat Desa Torjunan berada pada nilai ukur -3,2 (minus tiga koma dua). Secara teoritis yang dikemukakan oleh Reddin nilai nominal tersebut menunjukkan Klebun Torjunan kurang luwes dalam memanajemen laju roda pemerintahan khususnya dalam yang menyangkut birokratisasi dan hubungannya dengan pihak pemerintah Kecamatan Robatal. Hal ini dikarenakan programprogram baik pembangunan, peningkatan kesejahteraan, maupun administrasi telah diatur secara baku dalam peraturan dan undang-undang yang berlaku, sehingga Klebun maupun Kecamatan Robatal tidak dapat merubah ketentuan tersebut. Perubahan ketentuan program dapat berlangsung terdapat peraturan perundang-undangan dan izin dari pemerintah Kabupaten maupun Pusat atau sebab yang sangat genting sehingga harus dilakukan langkah darurat untuk mengatasinya.

Efektifitas Gaya Kepemimpinan Situasional Klebun (Kepala Desa) Torjunan Kabupaten Sampang terhadap laju roda pemerintahan Masyarakat Desa Torjunan berada pada klasifikasi $\mathrm{G}_{4}$. Klasifikasi tersebut menggambarkan bahwa Klebun Torjunan lebih efektif melakukan tindakan dengan cara melimpahkan pembuatan keputusan dan pelaksanaan kepada masyarakat. Tindakan tersebut efektif dilaksanakan oleh Klebun Torjunan khususnya dalammemanajemen laju roda pemerintahan Masyarakat Desa Torjunan Kabupaten Sampang agar program yang dicanangkan pemerintah dapat berjalan dengan 
Efektifitas Gaya Kepemimpinan dalam Memanajemen.... (Arnanda Ajisaputra)

lancar dan meminimalisir konflik yang ada. Mengingat masyarakat dengan karakteristik yang keras dan kemauan yang kuat tanpa didukung tingkat pendidikan yang tinggi, maka Klebun harus dapat mengayomi masyarakat dan terbuka kepada mereka tentang rencana-rencana program pembangunan baik fisik maupun non fisik. Klebun harus dapat mengambil hati masyarakat dan memahamkan mereka, sehingga apabila program pembangunan dijalankan konflik sosial terhadap masyarakat Desa Torjunan dapat diminimalisir dan seandainya terdapat konflik karena urusan kepentingan, masyarakat siap membantu agar program dapat berjalan kembali sebagaimana yang mereka harapkan.

\section{DAFTAR PUSTAKA}

Akadun. 2007. Administrasi Perusahaan Negara. Alfabeta. Bandung.

Budiardjo, Miriam. 1982. Dasar-Dasar Ilmu Politik. Gramedia. Jakarta.

Dewi, I Gusti Ayu Manuati. 2009. Model Kepemimpinan Efektif. Jurnal Ilmiah. Volume V No. 1 Juli 2009. ISSN : 1907-3275.

Faules, Gary., Jeans, Pace. 1998. Komunikasi Organisasi. Remaja Rosdakarya. Bandung.

Goleman, Daniel. 2005. Kepemimpinan Berdasarkan Kecerdasan Emosi. Gramedia. Jakarta.

Haricahyono. 1986. Ilmu Politik. Tiara Wacana. Yogyakarta.

Hendarso. 2006. Metodologi Penelitian Sosial. Kencana. Jakarta.

Kansil, Stefanus. 1986. Hukum Antar Tata Pemerintahan. Erlangga. Jakarta.
Lincoln, Davis., Guba, Paul. 1985. Naturalistic Inquiry. Sage Publication. London.

Matteson, Michael. 2002. Perilaku dan Manajemen Organisasi. Edisi 7 Jilid 2. Erlangga. Jakarta.

Moelong, Lexy J. 1990. Metodologi Penelitian Kualitatif. Remaja Rosda Karya. Bandung.

Muluk, Khairul. 2006. Desentralisasi dan Pemerintahan Daerah. Bayumedia. Malang.

Narbuko, Cholid. 2003. Metodologi Penelitian. BumiAksara. Jakarta.

Sujadi. 2005. Profesionalisme Birokrasi Dalam Pelayanan Publik. Penelitian Ilmiah: Tesis STIA. Malang.

Novita, Tresiana. 2007. Kualitas Pelayanan Institusi Publik: Tingkat Kepuasan Masyarakat (Analisis Tanggapan Kelompok Pelanggan R2A, R2B dan R1tentang Mutu Pelayanan Unit Pelayanan Masyarakat dan Unit Tehnik PDAM Way Rilau Kota Bandar Lampung). Jurnal Ilmiah, ISSN 1411 - 9366 Volume 3 No.2, Januari 2007.

Thoha, Miftah. 1983. Kepemimpinan Dalam Manajemen. BPFE UGM. Yogyakarta. 
